\section{World Bank evaluates the economics of tobacco}

The World Bank is to rel ease a report this month addressing concerns about the impact of tobacco control policies and tobacco-related heal th costs on international economies-an area that it feels has been neglected in the effort to stop an increasing percentage of the world's population from killing itself by smoking.

The report stems from a consultation session on the economics of tobacco control organized by the Bank at the $10^{\text {th }}$ World Conference on Tobacco in Beijing, China, 1997, which revealed that "the discipline of economics was not being applied to tobacco control in many countries."

The report points out that although the adverse health effects of tobacco are now widely appreciated, many governments are avoiding implementing tobacco control measures, such as increasing tax on tobacco, because they are frightened that reduced sales of cigarettes will lead to job losses, which will have a detrimental effect on local economies.

These fears are unfounded, concludes the report, and efforts to reduce tobacco use "would not cause long-term job losses in the vast majority of countries." It says that money currently spent on tobacco would be spent on other goods and services, thus generating new jobs to replace those connected with the tobacco industry. The report concedes, however, that the scope of the financial costs imposed on society by smokers "is still unclear."

Within the next year, tobacco is expected to kill approximately four million people worldwide. And by 2030 , says the report, this figure will rise to ten million deaths per annum-"more than any other cause and more than the projected death tolls from pneumonia, diarrheal diseases, tuberculosis and the complications of childbirth for that year combined." Most of these deaths will be in low-income and middle-income nations.

According to models used in the report, tax increases that raise the cost of cigarettes by ten percent worldwide would have caused 40 million smokers alive in 1995 to quit, and prevented a minimum of 10 million tobacco-related deaths. Tax currently accounts for around two-thirds of the retail price of a pack of cigarettes in high-income countries, but not more than half that in lower-income countries, where smoking is increasing at the fastest rate (Nature Med. 3, 1305; 1997).

Conservative estimates suggest that a 10 percent increase in cigarette tax in China, for example, would "decrease consumption by five percent, increase

\section{Biomedicine benefits from first JIF round}

British research in cell biology, vaccine development and 'post-genomics' have received a substantial boost in the first round of allocations of a new $£ 700 \mathrm{mil}$ lion ( $\$ 1.15$ billion) initiative to renovate the research infrastructure of universities. The so-called Joint Infrastructure Fund (JIF) was announced last year as part of a broad package of increased spending on research unveiled by the government (Nature M ed. 4, 871; 1998).

The JIF is restricted to financing "essential building, refurbishment and equipment projects." 180 applications were received for the first of five rounds of applications, from which 37, worth f150 million, were announced as having been selected for funding last month (120 applications were rejected, and decisions on the remainder have been deferred for further consideration). The next round will be announced in November.

Among the successful bidders was Richard Morris, professor of neuroscience at the University of Edinburgh, whose department had been seeking just under $\mathrm{f4}$ million to establish stateof-the-art facilities in molecular genetics. Morris' JIF grant-together with an extra $f 600,000$ that the university has agreed to contribute-will pay for the refurbishment of the university's pharmacology department, allowing for an increase from 12 to 15 research groups working in the new facilities. "I am delighted at being one of the lucky ones," says Morris. "I don't think that the government realized the full depth of need that revenue by five percent, and that the increase would be sufficient to finance a package of essential health services for one-third of China's poorest 100 million citizens."

Because efforts to reduce the supply of tobacco have not reduced consumption in any measurable way from 1991 to today, the report promotes a new strategy of reducing tobacco consumption, and points to wider access to nicotine replacement therapy (NRT) as one of the most effective methods.

Based on 1995 figures, the report claims that if only six percent of smokers used NRT to quit, one million lives could be saved. However, access to NRT varies: In the UK, for example, the poorest smokers are to be made eligible for limited free supply of NRT if they decide to quit; but in some middle-income countries and many low-income countries, NRT products are not available at all.

Last month the World Health Organization (WHO), cited in the report as the Bank's "partner... and principal international agency on health issues," stepped up its own anti-smoking campaign by calling for cigarettes to be regulated like prescription drugs, because they are nicotine delivery devices. The Bank report calls on UNICEF and the International Monetary Fund to reexamine their policies relating to tobacco. A copy of the report, Curbing The Epidemic: Governments and the Economics of Tobacco Control, is available at www.worldbank.org/hnp.

KaRen Birmingham, London

there was for this scheme, one that speaks to the needs of universities right across the UK."

Another successful recipient is the University of Newcastle, which will receive funds for the 'consolidation' of a new Institute of Human Genetics. Five of the 37 successful applications are from the University of Oxford, which will receive money for up-to-date imaging equipment for cell biology, and for the establishment of a center for clinical vaccinology and tropical medicine.

"This new fund is a welcome injection of capital into our universities," says George Radda, chief executive of the Medical Research Council. "Combined with existing funding arrangements, these grants will enable the United Kingdom to enjoy its position at the forefront of scientific achievement."

\section{DaVid Dickson, LONDON}

